\title{
The Perceived Self-Efficacy of Resource Rooms Teachers on Distance Learning Experience in Amman in Terms of Some Variables
}

\author{
Mirvat Y. Amirah ${ }^{1, *}$, Khaldoun A. Najadat ${ }^{2} \&$ Sara J. Mubarak $^{3}$ \\ ${ }^{1}$ Ministry of Education, United Arab Emirates \\ ${ }^{2}$ Ministry of Health, Jordan \\ ${ }^{3}$ Ministry of Education, Kuwait \\ *Corresponding author: Ministry of Education, UAE. Tel: 971-504-855-975. E-mail: \\ Mirvat_3amirah@yahoo.com
}

Received: March 16, 2021 Accepted: April 1, 2021 Published: May 24, 2021

doi:10.5296/ije.v13i2.18421ＵRL: https://doi.org/10.5296/ije.v13i2.18421

\begin{abstract}
This study aimed to examine the perceived self-efficacy of the resource room teachers for the distance learning experience in the capital Amman, Jordan in terms of some variables. To achieve this goal, 124 female resource teachers in government schools in the capital governorate were selected. The perceived self-efficacy measure was used to collect data. It is a valid and reliable measure that contains 25 items. The results showed that the level of perceived self-efficacy of the resource room teachers for the distance learning experience was moderate, as the mean of the overall tool was (3.16) with a moderate evaluation score. Table (3) shown that the averages of the tool's items ranged between (2.15-4.07). These averages didn't indicate statistically significant differences at $(\alpha \leq 0.05)$ for the variables: specialization, teacher's educational level, and number of students who receive service in the room. The data showed statistically significant differences at the $(\alpha \leq 0.05)$ for teacher's age variable in favor of the younger group. Also, the data showed statistically significant differences at the $(\alpha \leq 0.05)$ for the variable years of experience in favor of the least experience, less than 5 years.
\end{abstract}

Keywords: teachers self efficacy, resource room, distance learning 


\section{Introduction}

After the Covid-19 pandemic, the world has resorted to replace the direct education by distance education. This implies using new technologies in the field of education, so that teachers in this regard need to know how to use this technology to help them in the teaching process. Contemporary educational researchers discussed the importance of teachers' self-efficacy, which has been interpreted as teachers' perceptions about their teaching proficiency: teaching strategies and teaching effectiveness. (Al-Saadi, 2012)

The appropriate environment in education does not depend only on the learner and the school environment but extends to include the teacher as an effective main party that shares the same importance with other elements of the educational process. Researchers consider that the perceived self-efficacy of the teacher is one of the important dimensions of his personality. His beliefs about himself are an important basis for determining his behavior and actions in all areas. The results of many studies have discussed the effect of teacher's beliefs on his self-efficacy. The teacher's beliefs about himself give him a wide scope to develop his capabilities related to planning, implementing, and evaluating assigned tasks, and developing the skill of self-monitoring about the learning process that he provides to learners (Ali, 2004). Also, studies confirmed that the higher a student's level of self-efficacy, the greater his academic excellence (Mubaraka and Abu Mawloud, 2014). It was also found that self-efficacy plays a role in increasing student achievement (Al-Shamrani, 2014; Saeed, 2012).

Therefore, this study came to examine the understanding and perception of resource teachers about their self-efficacy in providing technological educational content to students in their experience of distance education. This study aimed to investigate the perceived self-efficacy of resource room teachers about the experience of distance learning in the governorate of the capital Amman in terms of some variables. To achieve study purposes, a questionnaire to reveal the level of self-efficacy of resource teachers was prepared.

\subsection{Study's Problem and Questions}

The interest in disabled students, who visit resource rooms frequently, increased and became a priority in Jordan after Covid-19, and moving towards distance education.

There are limited studies discussed this topic. However, awareness of those in this field about the importance of the teacher's role in developing the services provided to disabled children was deepened. The performance of students with disabilities is not less important than the rest of their colleagues in the school, therefore they need integrated educational process within schools, especially in the acceleration in their education because of using modern technology. This study tries to answer the following questions:

What is the level of perceived self-efficacy of resource room teachers to experience distance learning from the teachers' point of view?

Are there statistically significant differences at $(\alpha \leq 0.05)$ in the level of perceived self-efficacy of the resource room teachers for the distance learning experience from the teachers' point of 
view according to the variables: the teacher's age, specialization, years of experience, the educational level of the teacher, and the number of served students?

\subsection{Study's Significance}

This study acquires theoretical and practical importance because:

\subsubsection{First: The Theoretical Importance}

Most of the research studies have focused on studying the perceived self-efficacy of teachers in direct education of students in public classes, while this study focuses on studying the perceived self-efficacy of resource room teachers in distance education.

The increasing focus on managing the new imposed education process that uses modern technology.

Enriching the literature especially in the view of the scarcity of studies that have investigated this aspect.

\subsubsection{Second: practical importance}

This study is an extension of the studies that have investigated in the same field during the previous period.

It is one of the few studies in the Jordanian environment, as far as researchers know, that reveal the self-efficacy of resource room teachers in distance education.

The study constitutes an attempt to fill the deficiency in local, Arab, and international libraries by enriching them with more specialized studies in this field.

\subsection{Study's Objectives}

This study aims to:

Identify the perceived level of self-efficacy of resource room teachers regarding the experience of distance learning from the teachers' point of view.

Investigate the existence of statistically significant differences in the level of perceived self-efficacy of resource rooms teachers regarding the experience of distance learning from the teachers' point of view according to the variables: teacher's age, specialization, years of experience, teacher's educational level, and number of served students?

\subsection{Terms and Procedural Concepts}

Perceived self-efficacy: defined as the individual's belief, awareness, and perception that he has the capabilities to organize and implement the work procedures required to achieve specific production and achievements (Bandura, 2000, p3).

It is procedurally defined as: the total scores obtained by the resource room teachers in Amman on the self-efficacy scale used in the current study.

Resource room teachers: the teachers who have been chosen to teach students in the resource 
room in the Hashemite Kingdom of Jordan, and who have been selected and appointed to work in these rooms under the legislation and standards of the Jordanian Ministry of Education.

\subsection{Study's Limitations and Determinants}

Human limits: The application of the study was limited to the resource rooms $=$ teachers in the governorate of Amman.

Spatial boundaries: The study was conducted in resources rooms in Amman.

Temporal limits: The study was conducted in the first semester of the year 2020-2021.

Objective determinants: The perceived self-efficacy scale was applied after having its psychometric properties.

\subsection{Theoretical Framework}

Since the development of special education from the sixties of the last century until the third millennium and the radical changes that affected the educational concepts and services provided to students with disabilities in public schools, as stipulated by laws and legislation, the quest for providing services and keeping abreast of developments has begun to deliver quality educational services as their colleagues. Teachers' competencies are one of the quality indicators in this regard.

Educational competencies of resources room teachers have a functional role in the educational process. It was translated by developed countries in the form of educational competencies before and during the educational process, as well as translated in the form of organized training provided to teachers during their work in the resource rooms, as organizing educational and training programs for these teachers would raise students' level and solving future problems that may appear to them (Al-Qathami, 2001).

Modern technology and familiarity with modern programs are some of the indicators of any country's development regarding providing educational services to students with disabilities. Despite the rapid and continuous increase in the use and availability of computers and technology inside and outside the classroom in public schools, there is relatively little literature that has studied teachers' perceptions about their use of computers and self-efficacy using new technologies, as well as how these perceptions may affect their educational and professional practices and the positive effects of that practice in the future, especially in the view of the communication revolution and its acceleration in the world (Conceicao, Matt, Riesen, McDonnell, 2017).

Self-efficacy is one of the important dimensions in the personality of the teacher, as his beliefs about himself are an important basis for determining his behavior and actions in the personal, social and emotional areas. The results of many studies have indicated the importance of the beliefs of the self-efficacy of the individual, as perceived self-efficacy allows the individual to develop his capabilities related to planning, carrying out tasks, and the evaluation (Ali, 2004). In addition to that, teacher's perceptions about his self-efficacy 
play an important role in providing service to students and developing it (Al-Shamrani, 2014; Saeed, 2012). There is a relationship between psychological identity and a sense of self-efficacy, as there is an intersection between the associated convictions regarding the ability of performance and achievement and between self-related convictions (Al-Saadi, 2012).

Al-Waeli and Ala Al-Din (2013) reported that there is a common relationship between job satisfaction and perceived self-efficacy of the teacher through which it is possible to predict his successes and developing his students in the future.

The term self-efficacy appeared at the hands of the founder of social cognitive theory, Albert Bandura, in the seventies of the twentieth century. The term self-efficacy is given several names, including self-competence, self-worth, self-report, and self-perception. Bandura (1997) defined self-efficacy as the beliefs of people about their ability to produce effectively, and is seen as an important component of all important successes or failures that are attributed to the self, as it is a general, relatively stable, and variable characteristic over time with the accumulation of success and failure experiences for the individual. It determines an individual's general confidence and ability to succeed (Radwan, 2010).

Heshmat and Bahi (2006) believed that several criterias were showing that a person has positive self-efficacy. The person should be able to face difficulties and should have the ability to achieve, innovate and succeed according to his abilities, skills, and qualifications. He requires good physical health, and ability to choose realistic goals consistent with his capabilities and abilities. Also, he should have good social relations with others and seek to help them to achieve their needs, and have the potential to bear social responsibility. I addition to that, he should have an ability to understand himself and what it contains in terms of potentials, inclinations, and abilities, therefore, strive to form a good relationship with himself and accept it in the way it is, and seek to develop it to achieve self.

The most important challenges that resource room teachers face within regular schools are the tasks and requirements imposed by the inclusive education system. They require to be prepared to develop their students and raise their educational competence (Acedo, 2011). The perceived competence of the teacher about himself is also a requirement to achieve the desired goal. In general, the literature referred to two main dimensions stemmed from most of the definitions that linked competencies to teachers' development field. The first is the content of competencies, which includes: knowledge, skills, and schools. The second represents the degree of determining the knowledge, tasks, and skills included in the competencies, it may be a definition that may be translated in the form of observable and measurable educational outcomes (Tee, 2004).

The study of Rapoo (2001) aimed to examine the relationship between the teachers' perceived self-efficacy and between educational practices, gender, and academic achievement of secondary school students in South Africa. The sample consisted of (112) students, and the results indicated that the relationship between self-efficacy and gender was not significant.

Finson's study (2002) tested the relationship between teachers' self-efficacy beliefs and 
between the practice of a trained teacher for efficient educational methods and the teacher's perception of himself as a teacher. (135) teachers in the basic stage before university service participated in the study. To collect data, the tool of measuring the beliefs related to the self-efficacy of primary school teachers was used to reveal the perceptions of self as a teacher. The results indicated that teachers with high self-efficacy tend to practice teaching methods based on natural external activities, encourage work in groups, take into account individual differences, reduce their control over students, and believe in the ability of their students to learn. Unlike those with low self-efficacy who considered the role of the teacher as the main one, as he, from their perspective, explains his lessons without concern for student participation and interaction.

The study of Poulou (2007) aimed to examine the factors that pave the way to the beliefs related to the teachers' education efficiency in Greece. The considered efficiency's dimensions were classroom management, and belief that they can influence the effectiveness of educational strategies. The sample consisted of (198) teachers in the final university year. The measure of teacher competence and a measure of teachers' sense of competence were used. The results indicated that the efficiency factors of educational practices, personal characteristics, and motivation for education were the most contributing factors to predicting aptitude beliefs in education.

Hassouna's study (2009) aimed to identify the degree of self-efficacy in teaching among teachers of lower elementary stage before service, and reveal its effect in terms of gender. The researcher used a tool to measure beliefs related to self-efficacy in teaching on the study sample consisting of (194) teachers. The results showed that most of the sample members reported a medium or high degree of self-efficacy in teaching. Females surpassed males in both sub-scales in a statistically significant manner. Teachers with a high school diploma from the scientific branch outperformed the literary branch graduates in a statistically significant manner.

Lee and Tsai (2010) researched the extent of teachers' understanding of web-use to browse educational technology content, integrating web technology into their educational practices, and verifying the importance of teachers' self-efficacy and their perceptions of their competence in teaching, which is related to teaching strategies as well as the effectiveness of teaching through the use of these technologies. The researchers developed a new questionnaire, the Technological Survey of Cognitive Educational Content, to explore the self-efficacy of teachers, and assess their attitudes towards web-based teaching. The study sample consisted of 558 teachers from elementary to high school in Taiwan. The results indicated a lack of general knowledge about teaching methods related to the Web among the sample. The researchers tested the interrelationships between teachers' self-efficacy, their attitudes regarding web-based learning, and its correlation with their variables. The results proved correlations between self-efficacy and positive attitudes toward web-based education. Older and more experienced teachers had lower levels of self-efficacy concerning the use of these technologies, while teachers who have more experience using the web (including teaching) have higher levels of self-efficacy. 
In a study conducted by Al-Waili and Ala Al-Din (2013) aimed to examine the common relationship between the variables of job satisfaction, teacher self-efficacy and educational practices, and the predictive ability of teacher self-efficacy. The sample was (240) teachers in Amman, Jordan. The results indicated that all the variables were associated with positive statistically significant relationships. Perceptions of teachers' self-efficacy contributed uniquely and distinctively in explaining approximately $(53 \%)$ of the variation in job satisfaction, followed by human and cognitive educational practices. It was found that teachers' self-efficacy in influencing decision-making contributed uniquely and distinctively to explain approximately (46\%) of the variation in job satisfaction, followed by teachers' self-efficacy in education and student discipline. Female teachers compared to male teachers were more satisfied with their work and perceived themselves more efficiently in performing the tasks of their professional role, and more practicing for educational strategies. The differences were statistically significant. The study also revealed that there are statistically significant differences in the level of job satisfaction and self-efficacy of teachers and their educational practice. They are attributed to the level of educational qualification in favor of the group of high graduate studies. There was no statistically significant effect for the levels of educational experience on the two scales of educational qualification in favor of the postgraduate group. It was also found that there was no statistically significant effect of levels of educational experience on the measures of job satisfaction and educational practices. There were significant differences in Teachers' self-efficacy returns to levels of educational experience in favor of a group (1-5) years.

In a study conducted by Al-Sahli (2014) to reveal the level of perceived self-efficacy among teachers of children with ASD in Saudi Arabia in terms of some variables. The sample included the all-female teachers of children with ASD in Riyadh, who were 180 teachers. The results revealed a high level of personal and general self-efficacy among the teachers. There were no significant differences among the study individuals with relation to the variables: academic qualification, specialization, or years of experience.

The study of Conceicao Jameson, Riesen, McDonnell (2017) aimed to find the relationship between computer use and the self-efficacy of a sample of rural and urban teachers, as well as their perceptions of computer efficiency in education, and its impact on their performance in the pre-service teacher preparation program for teachers who work with students with mild disabilities. The researchers used the survey to collect data, and the results proved differences in the levels of perceptions of self-efficacy of teachers in rural areas compared to those in cities.

Omran (2017) conducted a study to detect the level of organization and competence for students with difficulty in writing expression and to identify if there is a correlation between self-efficacy and the perceived self-organization of this group of students. It also aimed to measure whether there are differences in the level of students' organization, and self-efficacy with relation to the gender variable. In addition to verify the existence of a predictive ability between a learner achievement and self-efficacy in written expression. The study sample was (116) students with a learning difficulty in Tartous. The researcher introduced a written expression test to detect students who have difficulty with written expression, then she 
prepared questionnaires of self-learning and self-efficacy for them. The results indicated a significant positive relationship between self-learning and perceived self-efficacy among students with writing difficulty. Also, there were no differences attributed to the gender variable.

Qandil (2019) conducted a study aimed to determine the ability of the perceived self-efficacy and the locus control to predict the competencies of inclusive education for teachers in regular schools in the Jordanian capital, Amman. The study sample consisted of (50) teachers. The results indicated that the level of perceived self-efficacy of teachers was high, as the mean of the perceived self-efficacy for the scale items was (3.95). The level of the internal locus control was high, as the mean of the internal locus control items from the scale of teachers' locus control was (3.02), while the level of the external locus control was moderate, as the mean of the external locus control items from the scale of teachers' locus control was (2.78). The level of inclusive education competencies for teachers in the public inclusive schools was high, with a mean of (3.74).

\section{Methodology}

\subsection{Study Approach}

The researchers used the descriptive approach in this study due to the nature of the study's goal of identifying the level of study variables, and knowing how predictable the perceived self-efficacy among resource room teachers for the distance learning experience from the teachers' point of view.

\subsection{Study Population}

The study population consisted of all resource room teachers of grades 1-8 in public schools in Amman, Jordan, who served 150 students according to the statistics of the Ministry of Education (Ministry of Education, 2015).

\subsection{Sample}

The researchers used the convenience sampling method and sent 150 questionnaires for female teachers of resource room via email, WhatsApp, and Facebook. The questionnaire page was visited 132 times and the questionnaires were filled 124 times. Table 1 shows demographical data for the sample. 
Table 1. Demographical Data for the Sample

\begin{tabular}{cccc}
\hline Variable & Level & Number & Percentage \\
\hline \multirow{3}{*}{ Teacher's age } & $20-30$ & 19 & $15.3 \%$ \\
& $30-40$ & 51 & $41.2 \%$ \\
Specialization & $40-50$ & 54 & $43.5 \%$ \\
& Special education & 79 & $63.7 \%$ \\
Years of & Educational specialization & 45 & $36.3 \%$ \\
experience & Less than 5 years & 24 & $19.4 \%$ \\
& 6-10 years & 52 & $41.9 \%$ \\
Level of education & More than 11 years & 48 & $38.7 \%$ \\
& Bachelor's degree & 97 & $78.2 \%$ \\
N of students in & Master's degree & 27 & $21.8 \%$ \\
resource room & $1-5$ & 20 & $16.1 \%$ \\
& $6-10$ & 18 & $14.5 \%$ \\
& $11-15$ & 86 & $69.4 \%$ \\
& & 124 & $100 \%$ \\
\hline
\end{tabular}

Table 1 shows that:

- The highest percentage of the participating teachers according to their age group is $43.5 \%$ for the group 30-40 years. While the lowest percentage is $15.3 \%$ for the group $20-30$ years.

- Regarding the university specialization of the sample, the highest percentage is $63.7 \%$ for "special education" while the lowest is $36.3 \%$ for "educational specialization".

- The experience range "6-10" years gets the highest percentage of participation, $41.9 \%$. The experience range "less than 5 years" years gets the lowest percentage of participation, $19.4 \%$.

- Based on the level of education, the sample consists of two groups: bachelor and post-graduate. The higher percentage of participants, $78.2 \%$, holds a bachelor's degree while the lower percentage has a post-graduate degree, $21.8 \%$.

- The participants who serve the number of students (11-5) consist the highest proportion of the sample, $69.4 \%$. The participants who serve the number of students (6-10) consist the lowest proportion of the sample, $14.5 \%$.

\subsection{Study Tools}

\subsubsection{The Perceived Self-efficacy Scale of Resource Room Teachers}

The perceived self-efficacy scale for teachers was developed. It consisted of 25 statements. To answer the questions, five-point Likert scale was used to interpret the means of the respondents' responses to each paragraph of the questionnaire and to each of its fields. Its range shown in the table (2): 
Table 2. 5-point Likert Scale

\begin{tabular}{cccccc}
\hline Point & 1 & 2 & 3 & 4 & 5 \\
\hline $\begin{array}{c}\text { The level of } \\
\text { acceptance }\end{array}$ & $\begin{array}{c}\text { Very low } \\
\text { level }\end{array}$ & Low level & $\begin{array}{c}\text { Moderate } \\
\text { level }\end{array}$ & High level & $\begin{array}{c}\text { Very high } \\
\text { level }\end{array}$ \\
\hline
\end{tabular}

This study used three categories to describe the average level of acceptance: high acceptance, moderate acceptance, and low acceptance. This equation was used to detect the proper level: The length of the category= the highest point-the lowest point/number of categories, so the length of the category $=5-1 / 3=1.33$. Therefore, the categories will be: low acceptance ( 1 to less than 2.33), Moderate acceptance (2.33 to less than 3.66), and High acceptance (3.66-5).

\subsection{Reliability}

To ensure the tool's reliability, we distributed the questionnaire twice to 30 individuals who were not included in the study. The time lag between the two waves of distributions was two weeks. We compared the Pearson correlation coefficient (PCC) in all items between the two distributions. The overall average of PCC was (0.75) which indicated the tool's reliability.

In order to assess the internal consistency, we used Cronbach alpha for the first wave. Cronbach alpha was (0.82) which indicated an acceptable value for internal consistency. Studies indicated (0.60) as a minimum acceptable value for internal consistency (Amir \& Sonderpandian, 2002).

\subsection{Statistical Analysis}

We used these equations via SPSS for analysis:

- Cronbach alpha and Pearson correlation coefficient: to ensure study tool's reliability.

- Frequencies and percentages: to detect participants' distributions based on their demographical variables.

- Means and standard deviations: to detect the levels of responses for all items.

- T-Test: on all the study's questions based on two variables; specialty and teacher's educational level.

- Analysis of Variance (ANOVA): on all the study's questions based on three variables; teacher's age, years of experience, and number of served students.

\section{Results}

This part includes the results of this study that aims to know the level of perceived self-efficacy regarding distance teaching for teachers of the resource room.

- Firstly, the results related to the first question: What is the level of the perceived self-efficacy regarding distance teaching for teachers of resource room (from their 
perspective)?

We answered this question by calculating the means and the standard deviations for all items of the tool that aimed to know the level of the perceived self-efficacy regarding distance teaching for teachers of the resource room.

The results show that the overall level of the perceived self-efficacy regarding distance teaching for teachers of resource room is moderate. The mean of all items is 3.16. The items' means vary between 2.15 and 4.07. The responses of nine items are classified as "high level of acceptance" with means vary between 3.37 and 4.07. The item that gets the order (1) is number (16) which states that "I will be able to bear the time it will take to answer the questions of students with disabilities while I teach them remotely." The item that gets the order (9) is number (1) which states that "When a student with disabilities performs better than usual in distance education, this is often due to the additional effort that the remote special education teacher has made with the student."

The responses of eleven items are classified as "moderate level of acceptance" with means vary between 3.56 and 2.46. The item number (2) gets the $10^{\text {th }}$ order. It states that "I am constantly trying to find better teaching methods with students with disabilities to teach them remotely in the resource room class." The item number (18) gets the order (20). It states that "When a student with a disability has difficulty grasping the general concepts of the lesson well while learning from a distance, I can find ways to teach him better in the resource room class."

The responses of five items are classified as "low level of acceptance". There means vary between 2.24 and 2.15. The item number (22) gets the order (21). It states that "I can decide on the time and duration of classes for the students in the school according to the need." The last ordered item is number (24) which states that "I see that I can continue with this type of education with students with disabilities for a longer time and other semesters."

This result can be interpreted based on challenges of distance teaching from the perspective of teachers. The importance of distance teaching appears as a modern technological teaching method, especially in COVID-19. Resource room teachers are required to Keep up with educational developments, so they should adopt proper teaching methods to teach individuals with learning disabilities, overcome the difficulties that encounter teaching, learning process and changing the teacher's role to a modern teacher uses distance education. The levels of the perceived self-efficacy regarding distance teaching for teachers of resource room are below expectations, this may be attributed to the low qualifications of the majority of the teachers, the little desire they have, and unequipped environment which limits teacher's role in developing distance learning.

Also, this result may be affected by the nonsatisfaction of teachers from administration performance. The resources to introduce and promote distance learning are limited and require specific potentials that are not found in usual schools.

This result may be referred also to the inability of the teacher to keep an eye on a student individually which may affect teachers' self-efficacy negatively. Indeed, teachers don't 
hesitate to show a negative attitude toward such education. And this is not because they don't work well, but because of the limited resources and poor infrastructure that don't help them to be distance teachers.

The results of this study confirmed the results of Hassounah's (2009) study which reported that the majority sample of teachers has a moderate level of self-efficacy. In addition, it agreed with the study of Lee and tasi (2019) which proved an effect for web-teaching methods on the self-efficacy of teachers. The results of this study contradict the results of Kandeel (20019) who proved high levels of perceived self-efficacy among teachers.

- Secondly, the results related to the second question: at $(\alpha \geq 0.05)$, are there significant differences for level of perceived self-efficacy regarding distance teaching for teachers of resource room based on variables (teacher's age, specialty, years of experience, and number of served students)?

In order to answer this question, we calculated the means and standard deviations of level of self-efficacy based on variables (teacher's age, specialty, years of experience and number of served students). Also, we applied "Independent Samples T-Test) on level of self-efficacy based on two variables: specialty and teachers' level of education. ANOVA has been applied also on the level of self-efficacy based on three variables: teacher's age, years of experience, and number of served students in the resource room. Here are the results:

Table 3. Results of Independent Samples T-test on Level of Self-efficacy Based on Specialty and Teachers' Level of Education

\begin{tabular}{ccccccc}
\hline Variable & Level & Mean & SD & T & df & Sig. \\
\hline \multirow{2}{*}{ Specialty } & Special education & 3.16 & 0.37 & \multirow{2}{*}{0.16} & \multirow{2}{*}{122} & \multirow{2}{*}{0.88} \\
Educational specialty & 3.17 & 0.33 & & & \\
Teachers' & Bachelor & 3.15 & 0.34 & \multirow{2}{*}{1.05} & \multirow{2}{*}{122} & 0.30 \\
educational level & Post-graduate & 3.23 & 0.37 & & & \\
\hline
\end{tabular}

Table 3 shows nonsignificant differences at $\alpha \leq 0.05$ for the level of perceived self-efficacy regarding distance teaching for teachers of resource room based on specialty and teacher's educational level. T values were 0.16 and 1.05 which are nonsignificant at $\alpha \leq 0.05$. 
Table 4. Results of ANOVA on the Level of Self-efficacy Based on Three Variables: Teachers' Age, Years of Experience, and the Number of Served Students in the Resource Room

\begin{tabular}{|c|c|c|c|c|c|c|c|c|c|}
\hline Variable & Level & Mean & SD & Outcome & $\begin{array}{l}\text { Sum of } \\
\text { Squares }\end{array}$ & $\mathrm{df}$ & $\begin{array}{l}\text { Mean } \\
\text { Square }\end{array}$ & $\mathrm{F}$ & Sig. \\
\hline \multirow{3}{*}{ Teacher's age } & $\begin{array}{l}20-30 \\
\text { years }\end{array}$ & 3.25 & 0.30 & $\begin{array}{c}\text { Between } \\
\text { groups }\end{array}$ & 2.24 & 2 & 1.12 & \multirow[t]{3}{*}{10.70} & \multirow[t]{3}{*}{0.00} \\
\hline & $\begin{array}{l}30-40 \\
\text { years }\end{array}$ & 3.01 & 0.33 & $\begin{array}{l}\text { Within } \\
\text { groups }\end{array}$ & 12.65 & 121 & 0.11 & & \\
\hline & $\begin{array}{l}40-50 \\
\text { years }\end{array}$ & 2.92 & 0.41 & Total & 14.89 & 123 & & & \\
\hline \multirow{3}{*}{$\begin{array}{c}\text { Years of } \\
\text { experience }\end{array}$} & $\begin{array}{c}\text { Less than } 5 \\
\text { years }\end{array}$ & 3.29 & 0.35 & $\begin{array}{c}\text { Between } \\
\text { groups }\end{array}$ & 1.49 & 2 & 0.75 & \multirow[t]{3}{*}{6.74} & \multirow[t]{3}{*}{0.00} \\
\hline & 6-10 years & 3.08 & 0.29 & $\begin{array}{l}\text { Within } \\
\text { groups }\end{array}$ & 13.40 & 121 & 0.11 & & \\
\hline & $\begin{array}{c}\text { More than } \\
11 \text { years }\end{array}$ & 3.05 & 0.36 & Total & 14.89 & 123 & & & \\
\hline \multirow{3}{*}{$\begin{array}{l}\text { Served students } \\
\text { in resource } \\
\text { room }\end{array}$} & $\begin{array}{c}1-5 \\
\text { students }\end{array}$ & 3.26 & 0.19 & $\begin{array}{c}\text { Between } \\
\text { groups }\end{array}$ & 0.51 & 2 & 0.25 & \multirow[t]{3}{*}{2.13} & \multirow[t]{3}{*}{0.12} \\
\hline & $\begin{array}{c}\text { 6-10 } \\
\text { students }\end{array}$ & 3.09 & 0.43 & $\begin{array}{l}\text { Within } \\
\text { groups }\end{array}$ & 14.38 & 121 & 0.12 & & \\
\hline & $\begin{array}{c}11-15 \\
\text { students }\end{array}$ & 3.20 & 0.29 & Total & 14.89 & 123 & & & \\
\hline
\end{tabular}

Table 4 shows that:

- There are significant differences at $\alpha \leq 0.05$ for the level of perceived self-efficacy regarding distance teaching for teachers of resources room based on teacher's age. $F$ value was 10.70 which is significant. In order to know the sources of differences, we applied Scheffe's method for multiple comparisons. The results show that the differences between age groups (20-30) and (30-40) came in favor of the (20-30) group at 3.25 average while the second group (30-40) was 3.01. In addition to that, there are differences in favor of the age group (20-30) when compared with the age group (40-50) at 2.92 .

- There are significant differences at $\alpha \leq 0.05$ for the level of perceived self-efficacy regarding distance teaching for teachers of resources room based on years of experience. $F$ value was 6.74 which is significant. In order to know the sources of differences, we applied Scheffe's method for multiple comparisons. The differences between the categories of years of experience (less than 5 years) and (6-10 years) came in favor of the group (less than 5). Also, there are favorable results to the category of (less than 5 years) when compared with the category of (more than 11 years) that has average 3.05.

- There are no significant differences at $\alpha \leq 0.05$ for the level of perceived self-efficacy 
regarding distance teaching for teachers of resource room based on the number of served students. F value was 2.13 which is nonsignificant.

This result can be explained by the fact that younger teachers are able to interact with the tremendous technological development and information revolution, which necessitates that the educational environment determines its future vision regarding the educational process, and that younger teachers are more likely to use distance learning and are more popular with it. Younger female teachers view e-learning more positively than older female teachers; When applying distance learning methods, they are able to do much of their professional duties at home while caring for children, and this result is consistent with the study of Lee and Tassi (2010), which showed that older and more experienced teachers have lower levels of self-efficacy.

\section{Suggestions and recommendations}

Based on the results of the study, it recommends the following:

- Developing training programs aimed at improving the perceived self-efficacy of resource room teachers using evidence-based scientific strategies.

- Conducting further studies aimed at studying perceived self-efficacy on students with disabilities and linking it to other variables.

- Conducting programs to strengthen special education teachers and train them to use distance education system at schools.

- Linking schools and other educational institutions with modern information networks.

- Focusing government efforts on raising the level of distance learning programs with students in resource rooms.

Based on the results of the study, it recommends the following:

- Providing functional internet connection while using the distance learning system and limiting its interruption.

- Preparing programs to train teachers and teach them to use the distance education system in schools.

- Linking the educational and pedagogical institutions with modern information networks.

- Conducting studies among teachers to find out their views on distance learning and its relationship to their level of self-efficacy.

- The necessity of spending and training by the government to use distance learning. 


\section{References}

Acedo, C. (2011). Preparing Teachers for Inclusive Education. UNESCO. https://doi.org/10.1007/s11125-011-9198-2

Ali, A. (2004). Metacognition and its relationship to academic self-efficacy at the Faculty of Education students (unpublished master's thesis). Assiut University, Assiut.

Al-Qathami, M., \& Al-Abd, Al-J. (2001). Educational competencies for teachers of infertile children with disabilities in Taif city in the Kingdom of Saudi Arabia (Unpublished master's thesis). Educational general quantity, University of Jordan.

Al-Saadi, M. (2012). The evolution of psychological identity and its relationship to expectations of self-efficacy among students (unpublished master's thesis). Amman Arab University, Amman.

Al-Saadi, M. (2012). The evolution of psychological identity and its relationship to expectations of self-efficacy among students (unpublished master's thesis). Amman Arab University, Amman.

Al-Shamrani, A. R. (2014). Academic self-efficacy and its relationship to academic achievement among gifted students in Al-Qunfudhah Governorate (unpublished master's thesis). Al-Baha University, Al-Baha.

Al-Shamrani, A-R. (2014). Academic self-efficacy and its relationship to academic achievement among gifted students in Al-Qunfudhah Governorate. (Unpublished master's thesis). Al-Baha University, Al-Baha.

Al-Simi, N. F. (2014). Perceived self-efficacy among women mothers with autism in the Kingdom of Saudi Arabia inlight of some changes (Unpublished master's thesis). educational general quantity, Yarmouk University.

Al-Waeli, S., \& Al-Din, J. (2013). Perceived self-efficacy and efficient educational practices as predictors of job satisfaction for teachers. Dirasat Journal, Educational Sciences, University of Jordan, Jordan, 40(2).

Bandura, A. (1997). Self-efficacy: The exercise of control. New York: W.H. Freeman and company.

Bandura, A. (1997). Self-Efficacy: The Exercise of Control. NY: Freeman.

Bandura, A. (2000). Exercise of Human Agency through Collective Efficacy. Current $\begin{array}{llll}\text { Directions in } \quad \text { Psychological } & \text { Science, } & \text { 9(3), } & \text { 75-78. }\end{array}$ https://doi.org/10.1111/1467-8721.00064

Blessed, M., Abi, M., \& Abdel, F. (2014). Self-efficacy and its relationship to academic compatibility of a sample of middle school students, a field study on a sample of students in the average of Ouargla. Journal of Human and Social Sciences, Qasidi Merbah University. 
Blessed, M., Abi, M., \& Abdel, F. (2014). Self-efficacy and its relationship to academic compatibility of a sample of middle school students, a field study on a sample of students in the average of Ouargla. Journal of Human and Social Sciences, Qasidi Merbah University,

Conceicao, M. A., Jameson, J. M., Tim, R., \& John, M. (2017). Special Education Teachers' Computer Use and Perceptions of Self-Efficacy. Urban and Rural Preservice, 35(3), 12-19. https://doi.org/10.1177/875687051603500303

Finson, K. D. (2002). Drawing a scientist: What we do and do not know after fifty years of drawings. School Science and Mathematics, 102(7), 335-345. https://doi.org/10.1111/j.1949-8594.2002.tb18217.x

Hassouna, S. (2009). Self-efficacy in science teaching among pre-service elementary school teachers. Al-Aqsa University Journal (Human Sciences Series), 13(2).

Heshmat, M., \& Bahi, M. (2006). Psychological compatibility and functional balance. Egypt: International House.

Ministry of Education-Oman. (2016). Indicators and Statistics Division, Muscat.

Poulou, M. (2007). Personal Teaching Efficacy and its Sources: Student Teachers' $\begin{array}{llll}\text { Perceptions. } & \text { Educational }\end{array}$ https://doi.org/10.1080/01443410601066693

Qandil, N. (2019). The predictive ability of the perceived self-efficacy and the control center in the competencies of inclusive education that teachers in regular schools in the work of the researcher (Unpublished PhD Dissertation). University of Jordan, Amman.

Radwan, S. (1997). Self-Efficiency Predictions: Theoretical Construction and Measurement. Journal, 51(25), 55, Social Affairs.

Saeed, F. (2012). The relationship between perceived self-efficacy, supra-cognitive thinking and academic achievement (unpublished master's thesis). Amman Arab University, Amman.

Saeed, F. (2012). The relationship between perceived self-efficacy, supra-cognitive thinking and academic achievement (unpublished master thesis). Publication Amman Arab University, Amman

Tardous, Y. I. (2017). Self-organization of learning and its relationship to perceived self-efficacy among students with difficulty with written expression. MA Thesis, Tishreen University.

Tee, C. T. (2004). Competency of special education teacher, Faculty of Education.

Toppoin, K., \& Maloney, S. (2005). The Routledge flamer reader in inclusive education. London \& New York: RoutledeFalmer. 


\section{Copyright Disclaimer}

Copyright for this article is retained by the author(s), with first publication rights granted to the journal.

This is an open-access article distributed under the terms and conditions of the Creative Commons Attribution license (http://creativecommons.org/licenses/by/3.0/). 